\title{
Allochthonous Matter Input in Two Different Stretches of a Headstream (Itatinga, São Paulo, Brazil)
}

\author{
Ana Adelina de O. Afonso ${ }^{*}$, Raoul Henry ${ }^{2}$ \& Rita C.S.Maimoni Rodella ${ }^{3}$. \\ Departments of Zoology, and Botany, Institute of Biosciences, UNESP, CP.510, 18618-000 \\ Botucatu-São Paulo, Brazil
}

\begin{abstract}
In two streches of the Itaúna stream, one in a gallery forest and the other in an herbaceous vegetation zone, litter matter input (sorted by leaves, ligneous and reproductive components) were measured during a year. In the gallery forest stretch, the direct input and lateral transport attained 713 g.m. $\mathrm{m}^{-2} \cdot$ year ${ }^{-1}$ and $421 \mathrm{~g} . \mathrm{m}^{-1}$. year ${ }^{-1}$, respectively. In contrast, the herbaceous vegetation stretch showed a direct litter input and lateral transport of only 86 g. $\mathrm{m}^{-2}$. year ${ }^{-1}$ and 124 g.m. $\mathrm{m}^{-1}$. year ${ }^{-1}$, respectively. The empoverishment of riparian vegetation had a significant effect on the decrease of allochthonous input to stream mainly by direct input. Peaks of direct input into Itaúna stream occurred during late dry season and in the early wet season. They were attributed to leaf fall from riparian trees and to enviromental conditions, such as wind. In March, which was the rainy season in this region, a peak of lateral transport was observed mainly in the herbaceous vegetation stretch, probably induced by runoff.
\end{abstract}

key words: allochthonous input; stream; riparian vegetation

\section{INTRODUCTION}

A great diversity of plant species occurs along the banks of Brazilian streams. These exchange zones between the terrestrial and aquatic ecosystems are called riparian zones. The riparian vegetation affects several characteristics of lotic environments, such as the quality and amount of litter input, the water temperature and light availability for photosynthesis (Oswood et al, 1995; Afonso \& Henry, in press). The litter can either fall to the streams directly from the canopy of the riparian vegetation or can be carried by the rainfall and the wind, providing a terrestrial input of organic matter (De La Rosa, 1995). Some researchers emphasize the role of allochthonous matter as a main resource of energy for the inhabitants of the small streams (Stewart \& Davies, 1990). According to the "River Continuum Concept" (Vannotte et al, 1980), modified by Bretschko (1995), the allochthonous contribution is an important organic matter input for the aquatic community, specially in head streams with protected riparian forests.
A qualitative and quantitative change on the riparian forest affects the litter input to the streams and thus can modify the structure of all the biotic community.

The main aim of this work was to study the composition, the seasonal variation and to quantify the annual input of the plant particulate organic matter (> 1mm; Cummins, 1974), from lateral banks of the stream as well as from the direct input (aerial way), in the two stretches of a riparian zone in a headstream (Itaúna stream, São Paulo, Brazil) having different floristic composition and conservancy.

Preliminary results about the organic matter input to the Itaúna stream and the composition, abundance and distribution of the aquatic fauna have been presented by Henry et al. (1994).

\section{MATERIAL AND METHODS}

The selected area for the study was the Itaúna stream, Itatinga, São Paulo State, Brazil (at $23^{\circ} 08^{\prime}$ $\mathrm{S}$ and $48^{\circ} 38^{\circ} \mathrm{W}$ ), a third order stream, a tributary of the Veados Stream that flows into the Jurumirim Reservoir (Paranapanema River). The

\footnotetext{
* Author for correspondence
} 
Itaúna stream presents a width extending from 3 to $5.5 \mathrm{~m}$ and a depth up to $0.6 \mathrm{~m}$.

Two stretches of this headstream were chosen for the study. The first (called Closed Area) is darkened by the presence of a gallery forest consisting of dense secondary vegetation, well protected from human action. About $500 \mathrm{~m}$ downstream, the other stretch (called Open Area) is composed of a prevailing herbaceous scattered vegetation where the incidence of solar radiation occurs directly in the water.

Ten contiguous areas $(10 \times 5 \mathrm{~m})$ were demarcated for species sampling, five in each bank of the Open Area of the lotic environment. Since a great number of lianas was observed along of all this stretch, the quantitative survey of the vegetation was carried out through an evaluation of the covering degree of the areas (Braun-Blanquet, 1979). In each area, the soil area (\%) covered by the species, the absolute frequency $(\%$ of occurrence of area containing each species, in relation to the total area) and the relative frequency were determined.

In the Closed Area, 20 sampling areas $(10 \times 10 \mathrm{~m})$, disposed in two zones of 10 contiguous and parallel areas, at the left margin of the stream, were selected. All the arboreous organisms with D.H.B. (diameter in a height of the breast) $\geq 10 \mathrm{~cm}$ in each area were recorded and identified and the perimeter and the height were measured. The following phytosociological parameters (MullerDombois \& Ellenberg, 1974) were determined: frequency, relative density and dominance, and the importance index. The Shannon-Wiener diversity index and the equitability (Krebs, 1979) were also computed.

In each one of the two areas, 6 litter trap boxes (having $0.9 \times 0.9 \mathrm{~m}$ with $0.15 \mathrm{~m}$ height and the bottom being composed of a screen of $1 \mathrm{~mm}$ mesh) were placed in $1.5-2.0 \mathrm{~m}$ height of the stream bed. For the lateral input, 6 boxes (having $0.45 \times 0.9 \mathrm{~m}$ with $0.15 \mathrm{~m}$ height and the bottom and the top covered by the screen and one of the heights open for the material input) were placed at both margins of the stream. Thirty six boxes were used. During a year (from October, 1990 to September, 1991), the allochthonous matter in the boxes were removed after two weeks and dried up to a constant weight (D.W.). Further, the material was divided in three fractions: leaves, woody and reproductive parts. The deposition rates of litter direct input to the stream were expressed in $\mathrm{mg} . \mathrm{m}^{-}$ ${ }^{2} \cdot$ day $^{-1}$ and in g. $\mathrm{m}^{-2}$.year ${ }^{-1}$ and the lateral input in $\mathrm{mg} \cdot \mathrm{m}^{-1} \cdot$ day $^{-1}$ and in $\mathrm{g} \cdot \mathrm{m}^{-1} \cdot$ year $^{-1}$.

\section{RESULTS}

Table 1 contains a species list found in the Open Area, disposed in a decrescent order of cover degree. Herbaceous species are the ones having the highest degree of coverage in the Open Area: Hedychium coronarium, Coix lacryma-jobi and Polypodium sp.. A liana, Cobaea scandens, showed also a great degree of coverage. The arboreous species in the Open Area presented a low value of cover. The species with higher frequency were: Cobaea scandens, Hedychium coronarium and Polypodium sp.. Two of these presented intermediate frequency $(10 \%>\mathrm{F}>$ 5\%): Pennisetum sp. and Datura suaveolens. The others presented low frequency values $(<5 \%)$.

Table 2 contains a species list found in the Closed Area and shows number of organisms, relative frequency, relative density, relative dominance, importance index and position according the importance.. In the Closed Area, twenty species presented no more than three organisms. The species with higher Importance Index (I. I.) were: Piptadenia gonoacantha, Bauhinia forficata, Acacia sp., Acacia polyphylla and Chorisia speciosa. The importance of $P$. gonoacantha was due to the abundance of the organisms concerning its biomass, evaluated by the basal area, that expressed the dominance degree. B. forficata and Acacia sp. presented high values of importance due to their abundance while A. polyphylla and $C$. speciosa had their importance related to the basal area.

A continuous distribution of trees higher than $26 \mathrm{~m}$ was observed, but most organisms presented a height extending from 4.5 to $20 \mathrm{~m}$.

Table 3 shows annual direct and lateral input of litter composition of each fraction in both studied areas. The Open Area stretch showed a direct input of only $86 \mathrm{~g} \cdot \mathrm{m}^{-2} \cdot \mathrm{year}^{-1}$. In contrast, in the Closed Area stretch, the annual direct aport attained $713 \mathrm{~g} \cdot \mathrm{m}^{-2}$.year ${ }^{-1}$.The Open Area stretch showed a lateral transport of only $124 \mathrm{~g} \cdot \mathrm{m}^{-1} \cdot \mathrm{year}^{-1}$ while the Closed Area showed 421g. ${ }^{-1}$.year ${ }^{-1}$. Leaves were the most important fraction in the litter composition of direct input and lateral transport, in both areas. 
Table 1 - Sampled species of riparian vegetation in the Open Area of the Itaúna stream (Itatinga, São Paulo). Cover area (C.A. = \% covering); absolute frequency (A. F.); relative frequency (R. F.); Habits (Herb. = herbaceous; Creep. $=$ creeping; Shr. $=$ shrub; Arb. $=$ arboreous $) ;$ not identified $(?)$

\begin{tabular}{|c|c|c|c|c|c|}
\hline Species & Family* & Habit & C. A. & A. F. & R. F. \\
\hline Hedychium coronarium Koening & 21 & Herb. & 39.70 & 90 & 11.25 \\
\hline Cobaea scandens Cav. & 14 & Creep. & 23.00 & 100 & 12.50 \\
\hline Coix lacryma-jobi L. & 13 & Herb. & 8.50 & 20 & 2.50 \\
\hline (?) Polypodium sp. & 15 & Herb. & 4.70 & 90 & 11.25 \\
\hline Thinouia mucronata Radlk. & 16 & Creep. & 3.50 & 20 & 2.50 \\
\hline Pennisetum sp. & 13 & Herb. & 3.20 & 50 & 6.25 \\
\hline $\begin{array}{l}\text { Datura suaveolens Humb. \& Bonpl. ex } \\
\text { Willd }\end{array}$ & 17 & Herb. & 2.60 & 40 & 5.00 \\
\hline Musa sp. & 10 & Herb. & 1.60 & 20 & 2.50 \\
\hline Bohemeria caudata $\mathrm{Sw}$. & 20 & Shr. & 1.20 & 30 & 3.75 \\
\hline Celtis aculeata $\mathrm{Sw}$. & 19 & Shr. & 1.10 & 20 & 2.50 \\
\hline Piper (cf.) gaudichaudianum Kunth & 12 & Herb. & 1.10 & 20 & 2.50 \\
\hline Bauhinia forficata Link & 4 & Arb. & 1.00 & 10 & 1.25 \\
\hline Acacia polyphylla DC. & 9 & Arb. & 1.00 & 10 & 1.25 \\
\hline (cf.) Chusquea sp. & 13 & Arb. & 0.90 & 20 & 2.50 \\
\hline Commelina sp.2 & 6 & Herb. & 0.60 & 10 & 1.25 \\
\hline Panicum sp. & 13 & Herb. & 0.50 & 20 & 2.50 \\
\hline Commelina sp. & 6 & Herb. & 0.50 & 30 & 3.75 \\
\hline Setaria poiretiana (Schult.) Hunth. & 13 & Herb. & 0.50 & 10 & 1.25 \\
\hline Croton floribundus Spreng & 7 & Arb. & 0.40 & 20 & 2.50 \\
\hline Canna indica $\mathrm{L}$. & 5 & Herb. & 0.40 & 10 & 1.25 \\
\hline Trimfetta semitriloba Jacq. & 18 & Shr. & 0.30 & 10 & 1.25 \\
\hline $\begin{array}{l}\text { Cabralea canjerana (Vell.) Mart. subsp. } \\
\text { canjerana }\end{array}$ & 8 & Arb. & 0.30 & 10 & 1.25 \\
\hline Erigeron bonariensis $\mathrm{L}$. & 2 & Herb. & 0.25 & 10 & 1.25 \\
\hline Vernonia polyanthes Less. & 2 & Shr. & 0.25 & 10 & 1.25 \\
\hline Asclepias curassavica L. & 1 & Herb. & 0.20 & 20 & 2.50 \\
\hline Panicum laxum Swartz. & 13 & Herb. & 0.20 & 10 & 1.25 \\
\hline Ricinus communis L. & 7 & Shr. & 0.20 & 10 & 1.25 \\
\hline Paspalum sp. & 13 & Herb. & 0.20 & 10 & 1.25 \\
\hline (cf.) Senecio sp. & 2 & Creep. & 0.20 & 10 & 1.25 \\
\hline Melinis minutiflora Beauv. & 13 & Herb. & 0.20 & 10 & 1.25 \\
\hline Piper sp. & 12 & Herb. & 0.20 & 10 & 1.25 \\
\hline Rhipsallis sp. & 3 & Herb. & 0.10 & 10 & 1.25 \\
\hline Miltonia flavensces Lindl. & 11 & Herb. & 0.10 & 10 & 1.25 \\
\hline Urtica sp. & 20 & Arb. & 0.10 & 10 & 1.25 \\
\hline Lepismium cruciforme (Vell.) Miq. & 3 & Herb. & 0.10 & 10 & 1.25 \\
\hline
\end{tabular}

\footnotetext{
*Family: 1-Asclepiadaceae 2-Asteraceae 3-Cactaceae 4-Caesalpiniaceae 5-Cannaceae 6-Commelinaceae 7-Euphorbiaceae 8-Meliaceae 9-Mimosaceae 10-Musaceae 11-Orquidaceae 12-Piperaceae 13-Poaceae 14-Polemoneaceae 15-Polypodiaceae 16-Sapindaceae 17-Solanaceae 18-Tiliaceae 19-Ulmaceae 20-Urticaceae 21Zingiberaceae
} 
Table 2 - Sampled species in the arboreous stratum of the Closed Area in Itaúna stream (Itatinga, São Paulo). Number of organisms (n); relative frequency (R. F.); relative density (R. D.); relative dominance (R. D. O.); importance index (I. I.); position according the importance (I. P.) of species

\begin{tabular}{|c|c|c|c|c|c|c|c|}
\hline Species & Family* & $\mathbf{n}$ & R. F. & R. D. & R. D. O. & I. I. & I. $\mathbf{P}$. \\
\hline Acacia. polyphylla DC. & 12 & 7 & 6.82 & 6.31 & 8.96 & 22.09 & 4 \\
\hline Acacia sp. & 12 & 9 & 9.09 & 8.11 & 5.00 & 22.20 & 3 \\
\hline Alchornea sidaefolia Muell. Arg. & 6 & 1 & 1.14 & 0.9 & 0.21 & 2.25 & 30 \\
\hline Allophyllus edulis Radlk & 16 & 1 & 1.14 & 0.9 & 0.34 & 2.38 & 27 \\
\hline Arecastrum sp. & 2 & 1 & 1.14 & 0.9 & 0.96 & 3.00 & 21 \\
\hline Astronium graveolens Jacq. & 1 & 2 & 2.27 & 1.8 & 0.16 & 4.23 & 17 \\
\hline Balfourodendrom riedellianu (Engl.) Engl. & 15 & 2 & 2.27 & 1.8 & 0.21 & 4.28 & 16 \\
\hline Bauhinia forficata Link & 5 & 13 & 11.36 & 11.71 & 5.39 & 29.00 & 2 \\
\hline Bombacacea $e$ & 4 & 2 & 1.14 & 1.8 & 0.87 & 3.81 & 19 \\
\hline Campomanesia guazumifolia (Camb.) Legr. & 13 & 1 & 1.14 & 0.9 & 0.36 & 2.40 & 26 \\
\hline $\begin{array}{l}\text { Cariniana cf. estrellensis (Raddi) O. } \\
\text { Kuntze }\end{array}$ & 10 & 1 & 1.14 & 0.9 & 1.11 & 3.15 & 20 \\
\hline Casearia silvestris $\mathrm{Sw}$. & 8 & 4 & 2.27 & 3.6 & 0.99 & 6.86 & 11 \\
\hline Cedrela fissilis Vell. & 11 & 1 & 1.14 & 0.9 & 2.90 & 4.49 & 14 \\
\hline Celtis iguane (Jacq.) Sarg. & 18 & 1 & 1.14 & 0.9 & 1.96 & 4.00 & 18 \\
\hline Chorisia speciosa St. Hill. & 4 & 6 & 6.82 & 5.41 & 8.02 & 20.25 & 5 \\
\hline $\begin{array}{l}\text { Chrysophyllum gonocarpum (Mart. \& } \\
\text { Eichl.) Engl. }\end{array}$ & 17 & 1 & 1.14 & 0.9 & 0.36 & 2.40 & 25 \\
\hline Croton floribundus Spreng & 6 & 7 & 6.82 & 6.31 & 5.46 & 18.59 & 7 \\
\hline Jacaranda micrantha Cham. & 3 & 2 & 1.14 & 1.8 & 2.85 & 5.79 & 12 \\
\hline Lonchocarpus sp. & 7 & 7 & 3.41 & 6.31 & 1.46 & 1.18 & 9 \\
\hline Machaerium cf. brasilienses Vog. & 7 & 3 & 3.41 & 2.7 & 0.82 & 6.93 & 10 \\
\hline Machaerium cf. stipitatum Vog. & 7 & 1 & 1.14 & 0.9 & 0.22 & 2.26 & 29 \\
\hline Ocotea sp.1 & 9 & 9 & 9.09 & 8.11 & 2.74 & 19.94 & 6 \\
\hline Ocotea $\mathrm{sp} .2$ & 9 & 1 & 1.14 & 0.9 & 0.42 & 2.46 & 23 \\
\hline Piptadenia gonoacantha (Mart.) Marchr. & 12 & 15 & 10.23 & 13.51 & 43.0 & 66.78 & 1 \\
\hline Phytolacaceae & 14 & 2 & 2.27 & 1.8 & 0.54 & 4.61 & 15 \\
\hline Trichilia clausseni C. DC. & 11 & 3 & 2.27 & 2.7 & 0.56 & 5.53 & 13 \\
\hline Undetermined 1 & & 1 & 1.14 & 0.9 & 0.23 & 2.27 & 28 \\
\hline Undetermined 2 & & 1 & 1.14 & 0.9 & 0.54 & 2.58 & 22 \\
\hline Undetermined 3 & & 1 & 1.14 & 0.9 & 0.39 & 2.43 & 24 \\
\hline Dead & & 5 & 4.55 & 4.5 & 2.39 & 11.44 & 8 \\
\hline
\end{tabular}

*Family: 1-Anacardiaceae 2-Areacaceae 3-Bignoniaceae 4-Bombacaceae 5-Caesalpineaceae 6-Euphorbiaceae 7-Fabaceae 8-Flacourtiaceae 9-Lauraceae 10-Lecythidaceae 11-Meliaceae 12-Mimosaceae 13-Myrtaceae 14Phytolacacea 15-Rutaceae 16-Sapindaceae 17-Sapotaceae 18-Ulmaceae

Table 3 - Annual direct and lateral input of litter and composition of each fraction in Itaúna stream (Itatinga, São Paulo)

\begin{tabular}{cccccc} 
& \multicolumn{2}{c}{ Annual Direct Input $\left(\mathrm{g} \cdot \mathrm{m}^{-2} \cdot \mathrm{y}^{-1}\right)$} & & Annual Lateral Input $\left(\mathrm{g} \cdot \mathrm{m}^{-1} \cdot \mathrm{y}^{-1}\right)$ \\
\cline { 2 - 4 } & Open Area & Closed Area & Open Area & Closed Area \\
\hline Total & 86 & 713 & 124 & 421 \\
\% leaves & 79 & 73 & 62 & 64 \\
\% reproductive parts & 12 & 21 & 31 & 31 \\
\hline
\end{tabular}


The daily values of direct input $\left(\mathrm{mg} \cdot \mathrm{m}^{-2} \cdot \mathrm{day}^{-1}\right)$ of the three different litter fractions in the Open Area and Closed Area are show in Figures 1 and 2, respectively.

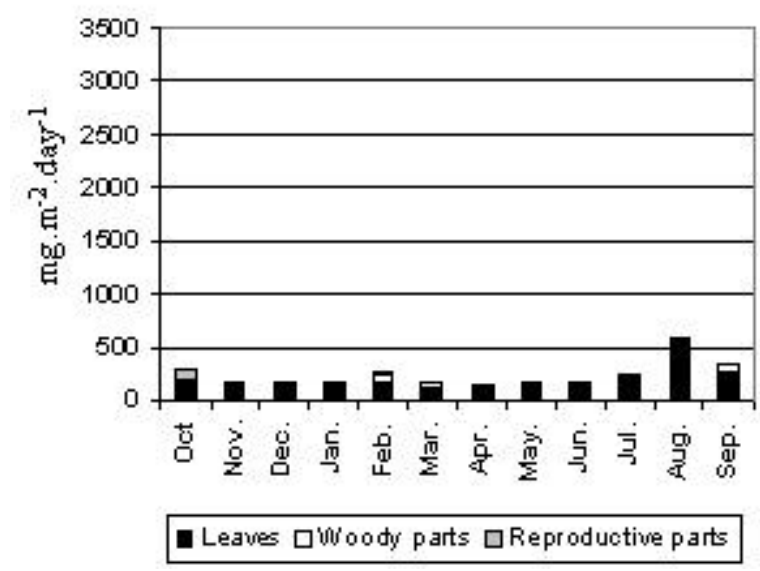

Figure 1 - Daily values of direct input of the three different litter fractions in the Open Area in Itaúna stream (Itatinga, São Paulo)

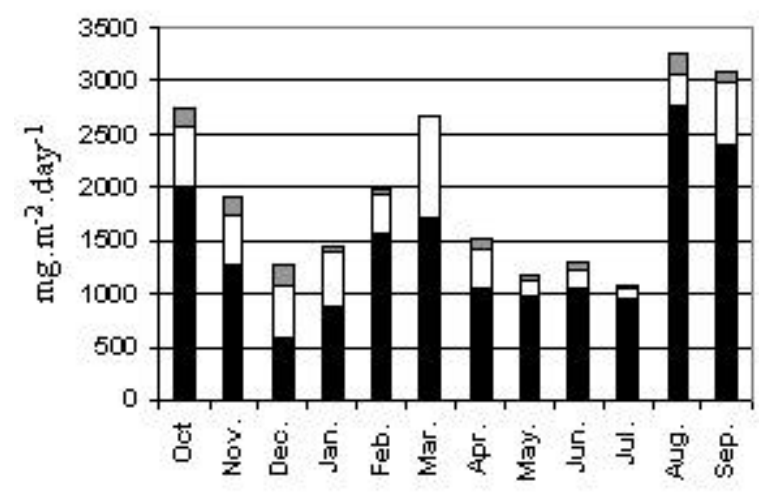

- Leaves a'vioody parts $\square$ Reproductive parts

Figure 2 - Daily values of direct input of the three different litter fractions in the Closed Area in Itaúna stream (Itatinga, São Paulo)

The peak on the direct litter input (584 mg. $\mathrm{m}^{-2} \cdot \mathrm{day}^{-1}$ ) in the Open Area, being $91 \%$ composed by leaves, was observed in August, 1991 (Figure 1). In the same month, the maximum peak $\left(3.257 \mathrm{mg} \cdot \mathrm{m}^{-2} \cdot \mathrm{day}^{-1}\right)$ of direct input during the year was observed in the Closed Area (Figure 2). In the Closed Area, high values were also found in September, 1991; October, 1990 and March, 1991 (Figure 2).
The daily values of lateral input (mg. $\mathrm{m}^{-1}$.day ${ }^{-1}$ ) of the three different litter fractions in the Open Area and Closed Area are show in Figures 3 and 4, respectively.

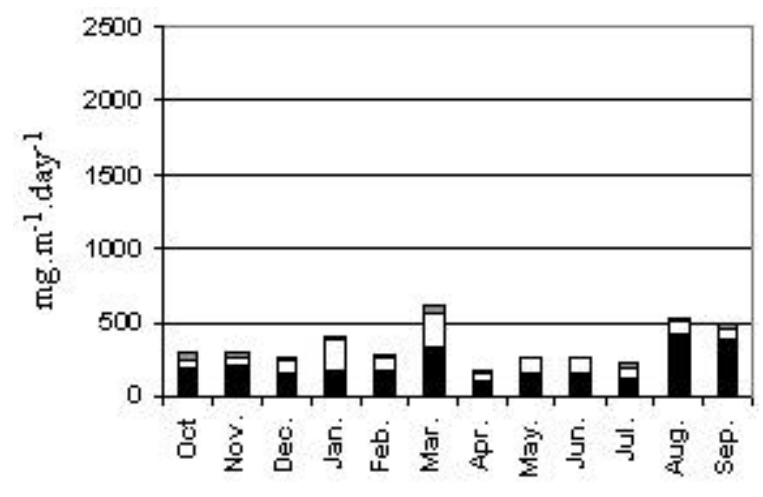

- Leaves a Woody parts aReproductive parts

Figure 3 - Daily values of lateral input of three different litter fractions in the Open Area in Itaúna stream (Itatinga, São Paulo)

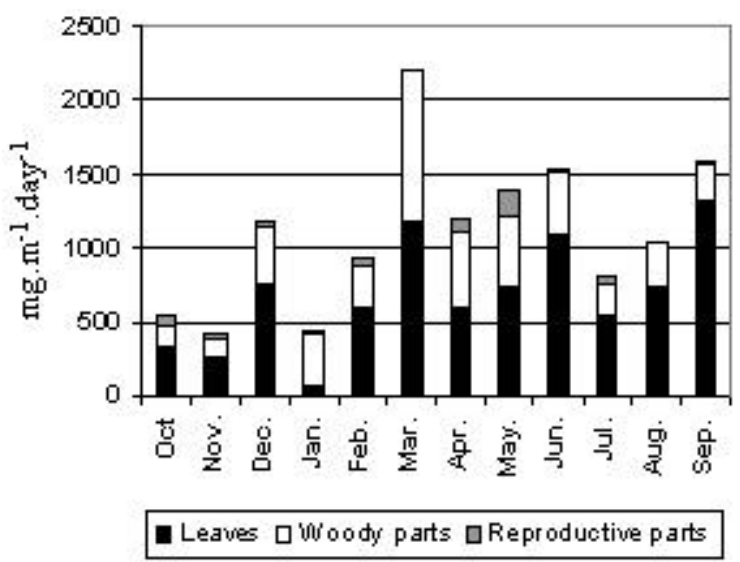

Figure 4 - Daily values of lateral input of three different litter fractions in the Closed Area in Itaúna stream (Itatinga, São Paulo)

In the Open Area, the maximum peak of lateral input $\left(620 \mathrm{mg} \cdot \mathrm{m}^{-1} \cdot \mathrm{day}^{-1}\right)$ was recorded in March, 1991 (Figure 3) being composed by leaves in the major part $(53 \%)$ of litter and by woody $(37 \%)$ and reproductive (10\%) fractions. High values of lateral input in the Open Area were also found in August $\left(517 \mathrm{mg} \cdot \mathrm{m}^{-1} \cdot \mathrm{day}^{-1}\right.$ ) and September, 1991 (494 mg. $\mathrm{m}^{-1}$.day $\left.{ }^{-1}\right)$ (Figure 3).

In the Closed Area, a peak of lateral input $\left(2.204 \mathrm{mg} \cdot \mathrm{m}^{-1} \cdot \mathrm{day}^{-1}\right)$ composed by leaves $(53 \%)$ 
and woody fraction (47\%) was also observed in March, 1991 (Figure 4).

\section{DISCUSSION}

Many species occurring in the Open Area are typical of disturbed areas, modified by anthropic activities. They are weeds (Leitão Filho et al., 1972; 1975; Lorenzi, 1982) such as Asclepias curassavica; Erigeron bonariensis; Vernonia polyanthes; Setaria poiretiana; Triumfetta semitriloba; Ricinus communis; Melinis minutiflora and Hedychium coronarium. All these species together presented a very significant cover value (41.6). The presence of these species was an evidence of the great vegetation modification caused by human impact in this stretch of the stream. Some arboreous species, commonly found in forests (Pagano \& Leitão Filho, 1987; Pagano et al., 1987), probably remaining species of the primitive vegetation or pioneer species of a feasible regeneration stage of the vegetation, could be observed in this area, such as Bauhinia forficata; Croton floribundus; Cabralea canjerana; Acacia polyphilla and Celtis aculeata. The presence of Cobaea scandens, from Mexico occurring in Brazil in a sub-spontaneous stage, was also recorded.

In the Closed Area, the human impact appeared to be less intense, since a vegetation having a forest physionomy was found in this stretch of the stream. However, such forests certainly presented some modifications due to wood removal (Huech, 1972). The species with high values of importance are commonly referred in surveys carried out in areas of mesophyll semideciduous forests from the Occidental Brazilian Plateau (Pagano et al.,1987; Bernacci \& Leitão Filho, 1996). The phytocenosis diversity index of the studied area could be considered high (4.24), due to the fact that a relatively small area was included in the survey, when compared with the values from other vegetations (Pagano \& Leitão Filho, 1987).

Several combined factors affect the amount and the quality of allochthonous input to the water. The environmental history of the region produces different riparian communities from that highly developed with deciduous trees up to that shaped by very spreadable formations (Oswood et al., 1995). The natural (such as fire and defoliation by insects) and anthropogenic disturbances (such as deforestation) are factors affecting the allochthonous input to the stream (Oswood et al., 1995). The seasonal climatic changes affect the biological cycles of the riparian vegetation and controls the allochthonous input to the stream (De La Rosa, 1995).

The lateral litter input presented highly variable values in function of factors such as the declivity of the banks on the streams (Weigelhofer \& Waringer, 1994) and local patterns of wind action (Webster et al., 1995). The litter input to a stream are controlled by the modifications on its quality and amount through the year, according to periodical events, individual history of the riparian species and drastic seasonal changes in some years (De La Rosa, 1995). The peculiar conditions of the riparian forest can determine the pattern of allochtonous input for rivers at different orders and sizes (De La Rosa, 1995). Another type of leaves, branches and organic matter input for the streams occurs from the wetlands, during the flood when water brings the material into the lotic environments (Webster et al., 1995).

The direct litter input in the Closed Area (Gallery Forest) in the Itaúna stream surpasses the values from other sites in the Southern Hemisphere (Table 4). The same can be evidenced for the lateral input.

It is expected that different forest ecosystems from various latitudes present differences in the litter production due to peculiar characteristics of the physical environment and the component plants. In forests from temperate zones, peaks on the litterfall occur in autumn due to the predominance of deciduous trees (Stewart \& Davies, 1990; Weigelhofer \& Waringer, 1994). In Eucalypt forests and temperate rainforests, the peak of litterfall is observed in the summer (Lake, 1995). In the Itaúna stream, the highest values of direct litter input were recorded in October, 1990 (the beginning of the rainy season), August and September, 1991 (the end of dry season). This trend is common in tropical rainforests (Spain, 1984). Morellato (1992) observed a seasonal litter production in the Japi Serra (Jundiaí, São Paulo) 
and a peak of leaves fall was found at the end of the dry season.

In both studied areas, the peak of lateral input (Figures 3 and 4) on the allochthonous plant matter was recorded in March, 1991 and probably is related with the rainy season in this region (Caramaschi, 1986). A relatively high contribution of woody fractions in the litter composition was determined in March, 1991 in the Open (37\%) as well as in the Closed Area (47\%) and probably this is due to water power in its removal. Leaching during the rain episodes can lead great amount of materials to the stream occurring, frequently, the litter lateral input. According to De La Rosa (1995), this influence is increased with the removal of the primary riparian vegetation. Besides the environmental conditions, a combination of two other factors can affect the lateral input: a) the plant material production and availability (from the neighbouring forest); b) the physical structure of the site that can present some barriers for the allochthonous matter input to the stream. A time gap can occur, between the litterfall in the forests and its input in to the stream (De La Rosa, 1995).

Plants with higher importance in the Gallery Forests certainly contribute with great biomass for the stream, compared with herbaceous plants having lower biomass. Comparing the data from the two areas of Itaúna stream, a significant modification on the litter input, in function of deforestation of the riparian zone, could be quantified and was clearly evidenced.

A research developed by Uieda \& Kikuchi (1995), at the same site and period, showed that the values of direct input of allochthonous plant material were higher during the rainy season (from October to March, corresponding to 460 and $145 \mathrm{mg} . \mathrm{m}^{-}$ ${ }^{2}$ day $^{-2}$ in the Closed and Open Areas, respectively) than in the dry season (from April to September, corresponding to 310 and $60 \mathrm{mg} . \mathrm{m}^{-}$ ${ }^{2}$.day $^{-1}$ in Closed and Open Areas, respectively). This trend was different from our data, but Uieda \& Kikuchi (1995) used other methodology for litter sampling (the floating trays) and the exposition time $(48 \mathrm{~h})$ was different. The prevalence of plant matter litter in the Closed Area in relation to the Open Area was also observed by Uieda \& Kikuchi (1995).

Table 4 - Annual direct $\left(\mathrm{g} \cdot \mathrm{m}^{-2} \cdot \mathrm{y}^{-1}\right)$ and lateral $\left(\mathrm{g} \cdot \mathrm{m}^{-1} \cdot \mathrm{y}^{-1}\right)$ input of allochthonous plant matter into streams of the Southern Hemisphere.

\begin{tabular}{|c|c|c|c|}
\hline Stream & $\begin{array}{l}\text { Direct } \\
\text { input }\end{array}$ & $\begin{array}{l}\text { Lateral } \\
\text { input }\end{array}$ & Reference \\
\hline $\begin{array}{c}\text { South. West } \\
\text { Cape }\end{array}$ & $\begin{array}{c}434- \\
500\end{array}$ & 32 & $\begin{array}{c}\text { King et } \\
\text { al., } 1987\end{array}$ \\
\hline $\begin{array}{l}{ }^{2} \text { Cement } \\
\text { Creek** }\end{array}$ & 604 & --- & $\begin{array}{l}\text { Blackburn \& } \\
\text { Petr, } 1979\end{array}$ \\
\hline $\begin{array}{l}{ }^{1} \text { Window } \\
\text { Stream* }\end{array}$ & 426 & --- & $\begin{array}{c}\text { Stewart \& } \\
\text { Davies, } \\
1990\end{array}$ \\
\hline $\begin{array}{l}{ }^{2} \text { Kepeel } \\
\text { Creek*** }\end{array}$ & 699 & --- & $\begin{array}{c}\text { Campbell } \\
\text { et al., } \\
1992\end{array}$ \\
\hline $\begin{array}{c}{ }^{2} \text { Lock } \\
\text { River** }\end{array}$ & 678 & --- & $\begin{array}{c}\text { Campbell } \\
\text { et al., } \\
1992\end{array}$ \\
\hline $\begin{array}{c}\text { Itaúna } \\
\text { stream** } \\
\text { (Gallery } \\
\text { Forest) }\end{array}$ & 713 & 421 & $\begin{array}{c}\text { Present } \\
\text { study }\end{array}$ \\
\hline $\begin{array}{c}\text { Itaúna } \\
\text { stream** } \\
\text { (Herbaceous) }\end{array}$ & 86 & 124 & $\begin{array}{l}\text { Present } \\
\text { study }\end{array}$ \\
\hline
\end{tabular}

Large amount of litter, an important source of allochthonous organic matter for the Itaúna stream, could be related to the "River Continuum Concept" (Vannote et al., 1980). According to the concept, "Low order rivers are predominantly storage, process and transport ecosystems of material coming from terrestrial zones". Drastic reductions on the plant matter to water occurred due to the removal of riparian vegetation from the Itaúna stream. Thus, the available energy for internal consumption can be reduced and modifies the autotrophy/ heterotrophy balance of the stream. Higher trophic levels of the food web (the benthic invertebrates and the fishes) of aquatic ecosystems can also be affected by the removal of the neighbouring forest, since it depends on the 
total amount and quality of available food for the consumers (Webster \& Benfield, 1986).

\section{ACKNOWLEDGEMENTS}

A. A. de O. Afonso is gratefull to FAPESP for a scholarship grant (Proc.89/3270-8). The authors would like to acknowledge to FAPESP for the finantial support (Proc.90/2410-8); to Prof. Lúcia Rossi from the Institute of Botany, São Paulo for the identification of the plant species; to Hamilton Antonio Rodrigues and Clemente José de Campos for the help in the field and laboratory work; to Prof. Carlos Roberto Padovani, Dept. of Biostatistics, Institute of Biosciences, Botucatu, for the statistical design of the experiments; to Mrs. Célia Guimarães for the English revision of the manuscript and to Aparecida dos Santos Oliveira for typing the manuscript.

\section{RESUMO}

A introdução de serapilheira (separada em folhas, galhos e partes reprodutivas) foi medida, durante 1 ano, em dois trechos do Córrego Itaúna, um em zona de mata galeria e outro em zona de vegetação herbácea. No trecho circundado por mata de galeria, a entrada direta e por transporte lateral atingiu $713 \mathrm{~g} \cdot \mathrm{m}^{-2} \cdot \mathrm{ano}^{-1}$ e $421 \mathrm{~g} \cdot \mathrm{m}^{-1} \cdot \mathrm{ano}^{-1}$, respectivamente. Por outro lado, no trecho circundado por vegetação herbácea, obteve-se valores de entrada direta de serapilheira e transporte lateral de somente 86 g.m $\mathrm{m}^{-2}$.ano ${ }^{-1}$ e 124 g. $\mathrm{m}^{-1}$.ano ${ }^{-1}$, respectivamente. O empobrecimento da vegetação ripária teve um efeito significativo na diminuição da entrada alóctone para o curso d'água principalmente por via direta. Ocorreram picos de entrada de serapilheira para o Córrego Itaúna no final da estação seca e começo da estação chuvosa, atribuídos à queda de folhas das árvores ripárias e às condições ambientais, como vento. Em março, foi observado um pico de transporte lateral principalmente no trecho de vegetação herbácea, provavelmente devido ao escoamento superficial.

\section{REFERENCES}

Bernacci, 1. C. \& Leitão Filho, H.F. (1996), Fauna fanerogâmica da floresta da Fazenda São Vicente, Campinas, SP. Rev.Brasil.Bot., 10 (2), 149-164

Blackburn, W. M. \& Petr, T. (1979), Forest litter decomposition and benthos in a mountain stream, Victória, Australia. Archiv.Für Hydrobiologie, 86, 453-498

Braun-Blanquet, J. (1979), Fitossociologia. H.Blume Ediciones, Madrid, 820p.

Bretschko, G. (1995), River/land ecotone: scales patterns. Hydrobiologia, 303, 83-91

Campbell, I. C.; James, K.; Hart, B.T.; Devereaux, A. (1992). Allochthonous coarse particulate organic material in forest and pasture reaches of two southeastern Australian streams. I. Litter acession. Freshwater Biology, 27, 341-352

Caramaschi, E. P. (1986). Distribuição da ictiofauna de riachos das Bacias do Tietê e Paranapanema, junto ao divisor de águas de São Carlos, (Tese de doutoramento), São Carlos, São Paulo, Brasil

Cummins, K. W. (1974). Structure and function of stream ecosystems. Bioscience, 24, 631-641

De La Rosa, C. (1995), Middle American streams and rivers. In- Ecosystems of the World 22 - River and stream ecosystems, ed. Cushing, C.E.; Cummins, K. W.; Minshall, G.W. Elsevier Science, pp.189-218

Henry, R.; Uieda, V. S.; Afonso, A. A. de O.; Kikuchi, R. M. (1994), Input of allochthonous matter and structure of fauna in a Brazilian headstream. Verh.Internat.Verein Limnol., 25, 1866-1870

Hueck, K. (1972). As florestas da América do Sul. Editora Polígono/Editora da Universidade de Brasilia, 466p.

King, J. M.; Day, J.A.; Davies, B. R.; Henshall-Howard, M.P. (1987), Particulate organic matter in a mountain stream in the South-Western Cape, South Africa. Hydrobiologia, 154, 165-187

Krebs, C. J. (1979), Ecology: the experimental analysis of distribution and abundance, Harper \& How, 694p

Lake, P. S. (1995), On floods and droughts: river and stream ecosystems of Australia In- Ecosystems of the World 22 - River and stream ecosystems, ed Cushing, C.E.; Cummins, K. W.; Minshall, G.W. Elsevier Science,.pp.659-694

Leitão Filho, H. F.; Aranha, C.; Bacchi, O. (1972), Plantas invasoras de culturas do Estado de São Paulo, .1, São Paulo, HUCITEC,. pp.5-291 
Leitão Filho, H. F.; Aranha, C.; Bacchi, O. (1975), Plantas invasoras de culturas do Estado de São Paulo, 2, São Paulo, HUCITEC,. pp.297-597

Lorenzi, H. (1982), Plantas daninhas do Brasil: terrestres, aquáticas, parasitas, tóxicas e medicinais. Nova Odessa, 425p.

Morellato, L. P. C. (1992), Sazonalidade e dinâmica de ecosssistemas florestais na Serra do Japi. In - História natural da Serra do Japi: ecologia e preservação de uma área florestal no Sudeste do Brasil, Morellato, L.P..Editora da UNICAMP/FAPESP, Campinas,São Paulo, 321p

Mueller-Dombois, D. Ellenberg, H. (1974) Aims and methods of vegetation. New York: John Wiley,. 547p

Oswood, M. W.; Irons, J. G.; Milner, A. M. River and stream ecosystems of Alaska (1995) In- Ecosystems of the World 22 - River and stream ecosystems, ed. Cushing, C.E.; Cummins, K. W.; Minshall, G.W. Elsevier Science,. pp. 9-32

Pagano, S. N. \& Leitão Filho, H. F.; Sheperd,G.J. Estudo fitosociológico em mata mesófila semidecídua no município de Rio Claro (Estado de São Paulo). Revta. Brasil. Bot., 10 (1), pp.49-61

Pagano, S. N.; Leitão Filho, H.F. Composição florística do estrato arbóreo de mata mesófila semidecídua no município de Rio Claro (Estado de São Paulo) (1987), Revta. Brasil. Bot., 10 (1),.pp 37-47

Spain, A. V. (1984), Litterfall and the standing crop of litter in three tropical Australian rainforests. J. Ecol., 72, pp.974-961
Stewart, B. A. Davies, B. R. (1990), Allochthonous input and retention in a small mountain stream, South Africa. Hydrobiologia, 202, pp.135-46

Uieda, V. S. \& Kikushi, R. M. (1995), Entrada de material alóctone (detritos vegetais e invertebrados terrestres) num pequeno curso d'água corrente na Cuesta de Botucatu, SP. Acta Limnologica Brasiliensia. VII, pp.105-114

Vannote, R. L., Minshall, G. W., Cummnins, K. W., Sedell, J.R., Cushing, C. E. (1980), The river continuum concept. Can. J. Fish Aquat. Sci,37, pp.130-37

Webster, J. R.; Wallage, J. B. \& Benfield, E. F. (1996), Organic processes in streams of eastern United States. In - Ecosystems of the world 22-River and Stream Ecosystems, ed. Cushing, C.E.; Cummins, K.W.; Minshall, G.W. Elsevier Science, .V, pp.117-187

Webster, V. R.; Benfield, E. F. (1986), Vascular plant breakdown in freshwater ecosystems. Ann.Rev.Ecol.Syst., 17, pp.567-594

Weigelhofer, G.; Waringer, J. A. Allochthonous input of coarse particulate organic matter (CPOM) in a first to fourth order Austrian forest stream. In. Revue ges. Hydrobiol., 79 (3), pp. 461-471.

Received: March 31, 1999; Revised: September 27, 1999 Accepted: October 29, 1999. 